Event-related GARCH:

the impact of stock dividends in Turkey

Roy Batchelor and Ismail Orgakcioglu 


\title{
Event-related GARCH:
}

\section{the impact of stock dividends in Turkey}

by

\section{Roy Batchelor and Ismail Orakcioglu}

City University Business School, London

\begin{abstract}
Cash dividends and rights issues on the Istanbul Stock Exchange are commonly accompanied by large stock dividend payments. This paper tests the proposition that stock dividends have no effect on company value, using a novel GARCH process with event-related intercept terms to capture induced changes in the volatility of stock prices. Returns rise in advance of stock dividend payments, but this effect becomes statistically insignificant when proper allowance is made for heteroscedasticity. Volatility rises after stock dividend payments, and this is attributed to persistence following exceptionally large price movements around the ex dividend day, rather than to any transitory rise in the unconditional returns variance. The study does document some irrationality in responses to cash dividends, with prices rising/ falling after increased/ decreased dividend payments, rather than after the much earlier dividend announcements.
\end{abstract}

Keywords: Event Study; GARCH; Share Prices.

Mailing Address: Professor Roy Batchelor, City University Business School, Frobisher Crescent, Barbican, London EC2Y 8HB, UK.

Email: r.a.batchelor@city.ac.uk 


\section{INTRODUCTION}

This study examines the behaviour of the prices of leading shares traded on the Istanbul Stock Exchange (ISE) in the weeks before and after the payment of stock dividends. We apply an event study methodology using pooled cross-sectional and time series data, with the novel twist that price movements through the event window are assumed to follow a mixture of GARCH processes. This allows us to measure and test the significance of stock dividends for both the level and volatility of share prices, and to control for the effects of the simultaneous payment of cash dividends.

In the United States stock splits and stock dividends are rare events, affecting in any year only about 5$15 \%$ of all traded stocks. These events tend to be triggered by particular firm characteristics - a sustained rise in price relative to the market, in the cases of stock splits, and a low dividend yield in the case of stock dividends (Lakonishok and Lev, 1988). Stock dividends ("scrip issues") and stock splits simply increase the number of shares in a company and so should reduce their value pro-rata, since the dividend or split does not in itself add value to the company. However, the prices of shares in US companies which announce a stock split typically rise in advance of the split (Fama et al, 1969; Grinblatt, Masulis and Titman, 1984; Lakonishok and Lev, 1987), and become more volatile afterwards (Ohlson and Penman, 1987). Increased volatility is also found in the studies of implied variances in the prices of options on splitting stocks by French and Dubovsky (1986) and Sheikh (1989). The rationale for the pre-split run-up in price is that investors interpret the split as a signal that the managers of the company expect its relative price rise to be permanent. In support of this idea, Fama et. al. (1969) show that pre-split price rises are sustained only if the company subsequently pays an improved dividend. No good rationale has been offered for the post-split increase in volatility, and Ohlson and Penman (1987) term it "an empirical aberration".

In Turkey, almost all major listed companies, regardless of performance, split their stock each year by means of stock dividends, which are typically paid alongside cash dividends and often accompany a rights issue. This has little to do with signaling, and everything to do with how high inflation impacts on the balance sheets of Turkish companies (see Aydogan and Muradoglu, 1998). Companies are obliged to revalue fixed assets each year by a factor close to the overall inflation rate, and this increase in value may be converted in whole or part to paid-in capital by means of the issue of stock dividends. In order to keep their debt: equity ratio below the regulatory limit, most companies choose to make this conversion. 
The frequency of stock dividends makes the ISE a convenient laboratory to test propositions about their effects on share values. Even though the source of the dividends should be well understood, there is scope for firms to exploit "money illusion" on the part of stockholders, by persuading them that stock dividends are a substitute for lower cash dividends, or represent a discount on the price of rights issues.

Section II of the paper introduces our data on stock prices and stock dividend events on the ISE. In Section III we develop a GARCH model for pooled cross-sectional and time series data. This allows for time-varying event-induced residual variances, and uses an array of dummy variables to test the statistical significance of changes in the mean and variance of daily returns around event dates, and to discriminate between the effects of cash and stock dividend payments. Section IV draws some conclusions.

We find no significant effects on returns from stock dividends either before or after their payment, but very large price volatility on the ex dividend day, presumably reflecting investor confusion as to the proper post-split value of the share. This spills over into the immediate post-dividend period, in a way well described by the GARCH model, and fully explains the apparently anomalous behaviour of volatility documented by Ohlson and Penman (1987). Real increases and decreases in cash dividends do cause returns to rise and fall after the dividend payment date rather than after the earlier announcement date, and we find evidence that firms and investors treat cash and stock dividends as substitutes. This suggests some degree of money illusion and irrationality in market reactions to dividend payments on the ISE.

\section{STOCK PRICES AND STOCK DIVIDENDS}

The Istanbul Stock Exchange started trading in its present form at the end of 1985, with around 80 listed shares. The market grew slowly until 1990, when as a result of the massive Turkish privatization program and the lifting of restrictions on inward investment there was a jump to over 100 in the number of listed companies, and trading volume increased from under 1 million per day (valued at around US\$3 million) to over 6 million per day (valued at US\$24 million). This growth has continued through the 1990s, and at end-1995 over 200 shares were listed and daily trades on the ISE averaged over US\$200 million. 
The raw data for this study are daily closing prices in the five-year period January 1990 - December 1994 of the 20 most important shares by market capitalization at the start of 1990 . The data were obtained directly from the Istanbul Stock Exchange. The companies, and their end-1994 market values, are listed on Table 1. All have annual dividend cycles, and almost all took the opportunity to make rights issues and distribute share dividends alongside their cash dividend payments in the period studied. A few companies also distributed stock dividends outside this cycle. Apart from any effects on company value, stock dividends and rights issues change the nominal prices of shares, and all of our price series are adjusted in proportion to the new share issues to compensate for these effects.

\section{II-A. Stock Prices}

Daily percentage log-return for each price series i are defined as $\mathrm{R}_{\mathrm{it}}=100 \cdot \ln \left(\mathrm{P}_{\mathrm{it}} / \mathrm{P}_{\mathrm{it}-1}\right)$, and $\mathrm{P}_{\mathrm{it}}$ and $\mathrm{P}_{\mathrm{it}-1}$ are the (adjusted) closing prices of share $\mathrm{i}$ on days $\mathrm{t}$ and $\mathrm{t}-1$ respectively. Table 1 shows alongside each company the average daily log-return, and the standard deviation of daily log-returns, in the years 1990-94. Average daily returns are high by the standards of developed markets, but this mainly reflects the high rate of inflation in Turkey. The annual inflation rates of 50-100 per cent per annum encountered in the early 1990s translate into a daily percentage log-return of 0.2218 per cent. Comparing this with the stock returns, it is evident that the value of many of the shares listed, and the ISE index itself (log-return 0.2029), actually fell in real terms over the sample period.

To assess the effects of cash and stock dividends on share values, it is important to clean prices of any effects which might be expected to occur as a result of general market movements, and work with the residual "abnormal" or "excess" returns series. Because of the importance of inflation in driving prices, we tentatively propose a two-factor model for ISE stock returns:

$$
\mathrm{R}_{\mathrm{it}}=\mathrm{R}_{\mathrm{ft}}+\beta_{\mathrm{i}}\left\{\mathrm{R}_{\mathrm{mt}}-\mathrm{R}_{\mathrm{ft}}\right\}+\delta_{\mathrm{i}} \pi_{\mathrm{t}}+\mathrm{r}_{\mathrm{it}}
$$

where $R_{i t}$ is nominal return, $R_{f t}$ is the nominally riskless return, $R_{m t}$ is the market return, $\pi_{t}$ is the expected rate of inflation, and the residual $r_{i t}$ measures abnormal returns. It is difficult to obtain a consistent series of interest rates for a nominally riskless asset in Turkey. We assume that the riskless rate consists of a real rate (which may itself depend on expected inflation) and a premium for expected inflation (which is related to past inflation $\mathrm{p}_{\mathrm{t}}$ ), so that $\mathrm{R}_{\mathrm{ft}}=\lambda_{1 \mathrm{i}}+\lambda_{2 \mathrm{i}} \mathrm{p}_{\mathrm{t}}$. Substituting in (1) the model becomes 


$$
\mathrm{R}_{\mathrm{it}}=\alpha_{\mathrm{i}}+\beta_{\mathrm{i}} \cdot \mathrm{R}_{\mathrm{mt}}+\gamma_{\mathrm{i}} \cdot \mathrm{p}_{\mathrm{t}}+\mathrm{r}_{\mathrm{it}}
$$

where $\alpha_{\mathrm{i}}=\left(1-\beta_{\mathrm{i}}\right) \cdot \lambda_{1 \mathrm{i}}$ and $\gamma_{\mathrm{i}}=\left\{\left(1-\beta_{\mathrm{i}}\right) \cdot \lambda_{2 \mathrm{i}}+\delta_{\mathrm{i}}\right\}$. Equation (2) can be estimated by OLS on the daily log-returns series, and the resulting parameter estimates are shown in Table 1.

In practice, there is little evidence of a significant inflation premium in any of the shares studied. Comovement with the market is important, however, and systematic risk accounts for some $35-55 \%$ of the variance of daily returns, so the variance of abnormal returns is about $45-65 \%$ of the variance of total returns. As might be expected, the betas of the shares in our sample of major companies do not deviate markedly from 1 . However, shares which underperform the index (e.g. Bagfas) do not necessarily have betas below 1, and outperforming shares (e.g. Ege Biracilik) do not necessarily have betas above 1 . This implies that there are important company-specific effects in returns which are not captured by the market model, but absorbed into the constant ( $\alpha$, price trend) terms in the regressions.

\section{II-B. Stock Dividends}

Table 2 lists the companies in our sample along with the number and type of "dividend events" with which they were associated during the years 1990-4. In total there are 20 companies x 5 cash dividend payments $=100$ cash dividend events,+11 additional stock dividend distributions, making 111 relevant events in our sample. However, in one case the adjusted price after the stock dividend distribution implied a huge $35 \%$ rise in company value on the dividend date, and we have dropped this outlier from the sample. Its inclusion would strengthen the findings artificially. All results below are based on data from the remaining 110 events.

The dividend events themselves are classified into five groups - (real) cash dividend increases, cash dividend decreases, cash dividend increases combined with a stock dividend, cash dividend decreases combined with a stock dividend, and pure stock dividend distributions. The Table also shows the frequency of rights issues by each company. These generally coincide with cash and stock dividend payments.

The size of cash and stock dividends are usually publicly announced well in advance of their payment. We have not been able to establish announcement dates for all the dividend payments early in our sample. However, for the years 1993-4, cash dividends are typically declared about 4-5 weeks before 
payment, while stock dividends and rights issues are announced much earlier, often 3-6 months before the event. There are some exceptional cases - for example, the Eczacibasi cash dividend in May 1994 was declared only 2 days before the ex-dividend date. In a few cases the size of dividends, cash and stock, are changed after their first announcement.

There is no obvious association in Table 2 of stock dividend payments with share price outperformance. Some companies which paid annual stock dividends were relatively fast-growing Arcelik, Eczacibasi, Koc. Others like Doktas and Demir Dokum were rather slow-growing. Similarly, there is no correlation between relative price performance and the number of rights issues.

Table 3, which aggregates events across companies and adds information on the average level of dividend payments, does provide some explanation for the incidence of stock dividends. Three points are apparent. First, when firms paid increased cash dividends, quite often (38/63 times, or 60\%) they also paid a stock dividend. In contrast, when firms paid a reduced cash dividend, they less often paid a stock dividend (17/ 37 times, or $46 \%$ ). This might indicate some signaling rationale for the stock dividend.

Second, there is a very strong association between rights issues and stock dividends. In our sample there are 54 rights issues, 49 of which were accompanied by stock dividends. This strongly suggests that stock dividends are used by companies in hope of reducing the apparent price to shareholder of the new stock. Indeed the stock dividends are termed bedelsiz artirim, meaning bonus- or free-shares.

Rights issues are heavily concentrated on firms and years when cash dividends are increasing. Of the 50 rights issues which were made simultaneously with dividend payments, $36(72 \%)$ coincided with an increased cash dividend. This explains better than any signaling argument why stock dividends correlate with improved cash dividends - both are associated with rights issues.

Third, regardless of whether the cash dividend is increased or reduced, or a rights issue made, the amount of the cash dividend is on average significantly lower if it is paid alongside a stock dividend. In the case of increased cash dividends, the average dividend paid was $232 \%$ if only the cash dividend was paid, but $102 \%$ if a stock dividend was also paid. It is approximately true that when a stock dividend is paid together with a cash dividend, the stock dividend is of equal apparent value, and reduces the cash dividend one-for-one. On average the 102\% improved cash dividend was paid alongside a $96 \%$ stock dividend. Where the cash dividend was reduced, on average a $46 \%$ cash dividend was paid alongside a 
53\% stock dividend. This strongly suggests that firms hope shareholders will regard cash and stock dividends not only as partial substitutes, but as almost perfect substitutes.

\section{THE EFFECTS OF STOCK DIVIDENDS}

We use an event study methodology to assess the impact of these cash and stock dividend payments on the prices of the underlying stocks. This involves extracting, for all companies and years, strips of abnormal return data for some window around the event dates of interest, and pooling the resulting time-series/ cross-section data to identify patterns which repeatedly occur before, at, or after the event date. The methodology has the disadvantage that information in the sample which falls outside the chosen data windows is not used. Care must also be taken to test for the validity of pooling from a heterogeneous collection of firms and years. The advantage of the methodology is that we do not have to control for the many other influences which impacted on excess returns throughout the sample. Implicitly, we assume that the dividend payments are the only significant factors affecting all prices in the weeks around the events.

The "event" which we examine is the actual payment of the dividend, and the event day is the exdividend date for the share. Most US studies, which tend to focus on the signaling hypothesis, look at market reactions after the dividend announcement date. However, as we have seen, there is no signaling rationale for stock dividends on the ISE. We look at returns in a window which runs from 30 trading days before the event date, to 30 days after. This is much shorter than the periods considered in parallel US studies, which typically look at the behavior of returns over periods of a year or more around the event dates. The smaller event window reflects the much greater frequency of stock dividend payments on the ISE.

Figures 1 and 2 show for each event type the behavior of average cumulative abnormal returns through this event window, where cumulative abnormal returns are defined as:

$$
\mathrm{c}_{\mathrm{ik}}=\sum_{s=-30}^{\mathrm{t}} \mathrm{r}_{\mathrm{is}}
$$

for day $t$ relative to the event day 0 . For straight cash dividend payments, cumulative returns rise for 10-15 days after the announcement of an improved dividend, and fall for 10-15 days after a dividend 
cut. For straight stock dividend events, cumulative returns start to rise about 10-15 days before the event date, and slowly fall thereafter. This mirrors closely the behavior of returns on US stocks around split announcement dates.

This pattern is also observed for compound cash and stock dividend events. In all these cases the price rises relative to the market (strictly, cumulative excess returns increase) in advance of the dividend date. If a stock dividend is paid and the cash dividend is increased, the higher price is sustained. If a stock dividend is paid and the cash dividend is cut, the price slowly drifts down, but does not actually fall as in the case of a pure cash dividend cut. This suggests that to some degree firms are indeed able to offset the impact of a lower cash dividend by offering a stock dividend. So firm behavior in sweetening low cash dividends with stock dividends is rational, even if investor reactions are not.

Table 4 shows mean returns and the standard deviation of returns in five windows around the event date - 30-11 days before, 10-1 days before, the event day itself, 1-10 days after, and 11-30 days after. The breaks 10 days before and after the event date were chosen because they are roughly the points at which local trends emerge and reverse in Figures 1 and 2. The mean returns in Table 4 therefore simply reflect the patterns in the Figures discussed above. But the standard deviations do contain additional interesting information.

The volatilities of excess returns for all types of events are similar prior to the event day. On the event day, the volatility of returns in the case of a pure stock dividend is much greater than in cases where cash dividends are also being paid. The volatility of returns continues to be high after the stock dividend date. There is therefore some evidence that the increased volatility observed after stock splits in US markets is also present on the ISE. The volatility of shares with high/ low returns following an improved/ worsened cash dividend also increases after the dividend date.

\section{III-A. Regression with Event Dummies}

We need some more formal way of testing the significance of these patterns in the mean and variance of returns. The issue is complicated by the fact that for many observations in our sample, more than one factor is affecting returns - for example a cash dividend and a stock dividend. The effects of a stock dividend could be estimated by considering only those cases where a stock dividend was paid, but no cash dividend. However, that would not use the sample data efficiently. 
To identify the separate effects of cash and stock dividends we have started by regressing returns on sets of dummy variables which take the values 1 or 0 depending on whether a cash dividend or stock dividend is present, and whether the returns come from the windows before, at, or after the event date. Specifically, we define

$S_{i t}=1$ if there is a stock dividend paid by company $i$ at the event date related to $t$, and 0 otherwise;

$\mathrm{U}_{\mathrm{it}}=1$ if an increased cash dividend is paid, and 0 otherwise;

$D_{i t}=1$ if a decreased cash dividend is paid, and 0 otherwise;

$\mathrm{T}_{\mathrm{jt}}=1$ if observation $\mathrm{t}$ is in the $\mathrm{j}$-th window, $(\mathrm{j}=1,2, . .5)$, around the event date, and 0 otherwise. The five windows are those of Table 4 , i.e.: $30-11$ days before, 10-1 days before, the event day 0, 1-10 days after, and 11-30 days after.

Excess returns $\mathrm{r}_{\mathrm{it}}$ can then be described as:

$$
\begin{aligned}
\mathrm{r}_{\mathrm{it}}= & \sum_{j=1}^{5} \mathrm{a}_{1 \mathrm{j}} \cdot \mathrm{T}_{\mathrm{jt}} \cdot \mathrm{S}_{\mathrm{it}}+\sum_{j=1}^{5} \mathrm{a}_{2 \mathrm{j}} \cdot \mathrm{T}_{\mathrm{jt}} \cdot \mathrm{U}_{\mathrm{it}}+\sum_{j=1}^{5} \mathrm{a}_{3 \mathrm{j}} \cdot \mathrm{T}_{\mathrm{jt}} \cdot \mathrm{D}_{\mathrm{it}} \\
& +\sum_{j=1}^{5} \mathrm{a}_{4 \mathrm{j}} \cdot \mathrm{T}_{\mathrm{jt}} \cdot \mathrm{S}_{\mathrm{it}} \cdot \mathrm{U}_{\mathrm{it}}+\sum_{j=1}^{5} \mathrm{a}_{5 \mathrm{j}} \cdot \mathrm{T}_{\mathrm{jt}} \cdot \mathrm{S}_{\mathrm{it}} \cdot \mathrm{D}_{\mathrm{it}}+\mathrm{v}_{\mathrm{it}}
\end{aligned}
$$

where we provisionally assume the residual $v_{\text {it }}$ has constant variance $h$, say, so $v_{i t} \sim N(0, h)$.

The coefficients on T.S measure the impact of a stock dividend (S) on abnormal returns in the window 11-30 days before the event $\left(T_{1}\right), 1-10$ days before the event $\left(T_{2}\right)$, on the event day itself $\left(T_{3}\right), 1-10$ days after $\left(\mathrm{T}_{4}\right)$ and 11-30 days after. Similarly the coefficients on T.U and T.D are estimates of the effects of pure cash dividends rising and falling. The coefficients on T.S.U and T.S.D measure interaction effects which occur when a stock dividend coincides with, respectively, a cash dividend rise or fall. The full effect on excess returns of a stock dividend combined with a reduced cash dividend would in event window $\mathrm{j}$ be the sum of the coefficients on T.S, T.D and T.S.D $=\left(a_{1 j}+a_{3 j}+a_{5 j}\right)$.

Under the assumption that the error terms are independent, normally distributed and homoscedastic, equation (4) can be estimated by ordinary least squares. This will recover as coefficients the mean effects shown in Table 4. For example, the coefficient $\mathrm{a}_{12}$ on $\mathrm{T}_{2 \mathrm{t}} \mathrm{S}_{\mathrm{it}}$, measuring the abnormal return during the period 1-10 days before a stock dividend, will be +0.7827 . The coefficient $\mathrm{a}_{42}$ on $\mathrm{T}_{2 \mathrm{t}} \mathrm{S}_{\mathrm{it}} \mathrm{U}_{\mathrm{it}}$, measuring the interaction effect of a stock dividend and an increased cash dividend in the 10 days 
before a dividend date, will from Table 4 be 0.2294 (joint effect) - 0.7827 (stock dividend effect) 0.1274 (cash dividend effect) $=-0.6807$. The benefit of the regression framework is not that estimates are obtained of the mean effects themselves, but that estimates are also obtained of the standard errors of the coefficients, and these may let us test the significance of the observed effects.

When (4) is estimated by OLS, none of the coefficients on events in the outer windows T1 and T5 is statistically significant. Since (4) is already highly parameterised, we simplify the model by constraining these coefficients to be equal to a constant $\mathrm{a}_{0}$. The model then simplifies to:

$$
\begin{aligned}
\mathrm{r}_{\mathrm{it}}=\mathrm{a}_{0} & +\sum_{j=2}^{4} \mathrm{a}_{1 \mathrm{j}} \cdot \mathrm{T}_{\mathrm{jt}} \cdot \mathrm{S}_{\mathrm{it}}+\sum_{j=2}^{4} \mathrm{a}_{2 \mathrm{j}} \cdot \mathrm{T}_{\mathrm{jt}} \cdot \mathrm{U}_{\mathrm{it}}+\sum_{j=2}^{4} \mathrm{a}_{3 \mathrm{j}} \cdot \mathrm{T}_{\mathrm{jt}} \cdot \mathrm{D}_{\mathrm{it}} \\
& +\sum_{j=2}^{4} \mathrm{a}_{4 \mathrm{j}} \cdot \mathrm{T}_{\mathrm{jt}} \cdot \mathrm{S}_{\mathrm{it}} \cdot \mathrm{U}_{\mathrm{it}}+\sum_{j=2}^{4} \mathrm{a}_{5 \mathrm{j}} \cdot \mathrm{T}_{\mathrm{jt}} \cdot \mathrm{S}_{\mathrm{it}} \cdot \mathrm{D}_{\mathrm{it}}+\mathrm{v}_{\mathrm{it}}
\end{aligned}
$$

The resulting parameter estimates are shown in full on Table 5. To illustrate the workings of the model, Figure 3 shows the pattern implied for mean excess returns to a share experiencing a stock dividend and a reduced cash dividend, which is now $\left(a_{0 j}+a_{1 j}+a_{3 j}+a_{5 j}\right)$. For this kind of event, excess returns rise $a$ little ahead of the dividend date, rise sharply on the event day, and fall immediately afterwards.

The estimated rise in returns in the 10 days before a pure stock dividend payment, measured by the coefficient $\mathrm{a}_{12}$, is a little higher than previously estimated (0.8089 rather than 0.7827$)$ as a result of the constraints. It is statistically significant at the $5 \%$ level. The coefficient $\mathrm{a}_{24}$ measuring the rise in returns in the 10 days after a cash dividend increase is also significant. However, the fall in returns after a decreased cash dividend does not appear to be statistically significant, and no other significant effects on expected returns - including those on Figure 3 - are found from the regression.

\section{III-B. A GARCH Model for Event Data}

Unfortunately, the assumptions which would support OLS-based inference from Equation (5) are unlikely to be observed in most event study samples. The main problem is that the residuals in (5) do not have constant variance. There are three sources of heteroscedasticity, the first two well recognized in the event study literature, the third also very familiar in empirical finance but relatively neglected in event study applications. 
First, the model pools data from a number of different companies and time periods. The event study methodology means we necessarily constrain the effects of, say, stock dividends on mean returns to be equal across companies. But there is no reason why the variance of returns should be constant across companies, and we have seen in Table (1) that there are sizable differences in the variance of excess returns to companies in our sample. This type of heteroscedasticity can be easily handled in a traditional regression framework, by normalizing the data - that is, by dividing all the observations on each company or event by the standard deviation of observations across that company or event, prior to estimation by OLS.

Second, there is no reason why the variance of returns should be constant throughout each event window. Indeed, the US research discussed above finds that the variance of returns may differ for each stock dividend event between the pre- and post-event periods, so this is an important hypothesis for investigation. This could also in principle be handled by a data normalization - for example, by dividing each observation not by the whole-event sample standard deviation, but by the standard deviation within the relevant inside-event window to which the observation belongs. This approach is suggested by Boehmer et. al. (1991). Heteroscedasticity of this kind we term event-related conditional heteroscedasticity.

Third, the generalized autoregressive heteroscedasticity (GARCH) model of Bollerslev (1986) has been found to provide a good description of the variance of daily stock returns - see, for example, Akgiray (1989) and de Santis and Imrohoroglu (1997). In this model, any large shock to a share price which causes an exceptionally high or low abnormal return on a particular day, also causes the variance of returns to be high on the following day, and to decay only slowly back to its long run average "unconditional" value. So if a dividend event causes a large mispricing on the ex-dividend day, say, prices are likely to be volatile for many days thereafter. Although there is much discussion of "eventinduced variance" in the event study literature (e.g. Brown and Warner, 1985), few studies take the step of characterizing the variance of returns as a GARCH process, perhaps because of the computational problems discussed below.

In our context, the simplest GARCH(1,1) model for the variance of excess returns for event $\mathrm{i}$ is:

$$
\begin{aligned}
& \mathrm{v}_{\mathrm{it}} \sim \mathrm{N}\left(0, \mathrm{~h}_{\mathrm{it}}\right) \\
& \mathrm{h}_{\mathrm{it}}=\mathrm{b}_{\mathrm{it}}+\mathrm{c}_{1 \mathrm{i}} \cdot \mathrm{v}_{\mathrm{it}-1}{ }^{2}+\mathrm{c}_{2 \mathrm{i}} \cdot \mathrm{h}_{\mathrm{it}-1}
\end{aligned}
$$


where $v_{i t}$ is the "shock" to returns on day $t$ of event $i$, and $h_{i t}$ is the time-varying variance of returns. The GARCH equation (6) makes the variance on day $t$ be conditional on the variance of the previous day $\left(\mathrm{h}_{\mathrm{it}-1}\right)$ and the most recent squared shock $\mathrm{v}_{\mathrm{it}-1}{ }^{2}$. In a steady state, with the squared shock set to its expected value $h_{i t-1}$, and variance constant over time so that $h_{i t-1}=h_{i t}=h_{i}$, the unconditional variance of event $i$ is

$$
\mathrm{h}_{\mathrm{i}}=\frac{\mathrm{b}_{\mathrm{it}}}{1-\mathrm{c}_{1 \mathrm{i}}-\mathrm{c}_{2 \mathrm{i}}}
$$

In the GARCH model, a large shock to returns will raise the variance of returns on the day following the shock, by an amount which depends on the size of coefficient $c_{1 i}$. On subsequent days, provided no further shocks occur, the variance will gradually return to the long run level described by (8). Any oneoff shock to returns will therefore have a persistent effect, raising variance for a number of days afterwards. The degree of persistence depends on the size of coefficient $c_{2 i}$.

A general model would allow the variance to differ across companies and events (subscript i) and also across days within each event window (subscript $t$ ), the first two sources of heteroscedasticity described above. This is the full event-related GARCH model. By analogy with (5), we set

$$
\begin{aligned}
b_{i t}=b_{0 i} & +\sum_{j=2}^{4} b_{1 j} \cdot T_{j t} \cdot S_{i t}+\sum_{j=2}^{4} b_{2 j} \cdot T_{j t} \cdot U_{i t}+\sum_{j=2}^{4} b_{3 j} \cdot T_{j t} \cdot D_{i t} \\
& +\sum_{j=2}^{4} b_{4 j} \cdot T_{j t} \cdot S_{i t} \cdot U_{i t}+\sum_{j=2}^{4} b_{5 j} \cdot T_{j t} \cdot S_{i t} \cdot D_{i t}
\end{aligned}
$$

Here, the coefficient $b_{22}$, say, measures any increase in variance 1-10 days before $\left(T_{2 t}=1\right)$ a cash dividend increase $\left(\mathrm{U}_{\mathrm{it}}=1\right)$. As in (5) we assume that the variances in the outer windows, 11-30 days before and after the events are equal, and are captured in the terms $b_{0 i}$. Since it is reasonable to assume that the unconditional variance stays constant for each company over time, we write:

$$
\mathrm{b}_{0 \mathrm{i}}=\sum_{k=1}^{20} \mathrm{~b}_{\mathrm{k}} \mathrm{E}_{\mathrm{ik}}
$$

where the $\mathrm{E}_{\mathrm{ik}}$ are dummies taking the value 1 if event $\mathrm{i}$ relates to company $\mathrm{k}$, and zero otherwise.

Thus for each company the unconditional variance is still described by (8) with $b_{i t}=b_{0 i}$, since the event and time dummies are zero outside the event window. However, within the event windows $j=2,3,4$ 
immediately before, during and after the event, the event-related conditional variance may temporarily be higher or lower than this long run level. For example, for a company paying an increased cash dividend $\left(U_{i t}=1\right)$ the event-related variance in the period $j=2$ immediately before the dividend payment would be $\left(b_{0 i}+b_{22}\right) /\left(1-c_{1 i}-c_{2 i}\right)$. If $b_{22}$ were significantly positive, this would be greater than the long run unconditional variance $\mathrm{b}_{0 \mathrm{i}} /\left(1-\mathrm{c}_{1 \mathrm{i}}-\mathrm{c}_{2 \mathrm{i}}\right)$. The overall conditional variance will then depend through the GARCH model (6) - (10) on the company concerned, the type of event, the relationship of day t to the event date, and (the autoregressive component) on the size of recent shocks to returns.

To illustrate the workings of the model, and anticipating some of the estimation results below, Figure 4 shows the behavior of the unconditional, event-related conditional, and overall conditional variance for firms that paid an increased cash dividend and no stock dividend. The event-related conditional variance rises before the dividend date, falls sharply on the dividend date itself, rises even more sharply immediately afterwards, and finally falls back to its long run level. The overlaid GARCH process causes the overall conditional (actual, observed) variance to smoothly transit from one level of the unconditional variance towards the next. The conditional variance therefore starts rising in advance of the dividend date, falls only slightly on the dividend day, rises further after the increased dividend is paid, and falls very gradually back to its long run level.

The parameters of the system (5)-(7), (9)-(10), must be estimated by maximum likelihood. The system is highly parameterised, and it proved impossible, even after a lengthy search using a combination of simplex and Berndt-Hall-Hall-Hausman (1974) algorithms, to obtain a solution without further constraints on the system. We have chosen to impose the restriction that the GARCH parameters $c_{1 i}$ and $c_{2 i}$ are equal across companies, equal to $c_{1}$ and $c_{2}$ respectively. This is less restrictive than it might appear. For example, the J. P. Morgan RiskMetrics system assumes return variances can be described by an exponential smoothing model similar to (6) with common parameters across all asset classes and all markets, and Guldimann (1995) adduces evidence to show that this approximation is acceptable.

The parameter estimates for the constrained model are shown on Table 6. We have not shown the company-specific constant terms in the variance equation in full, but simply the average across companies, and the range. As might be expected, the unconditional variances by company for the event subsamples resemble the whole-sample residual variances implied by the market model standard errors in Table 1. We have however, set out all the event effects on the variances - the parameters of (9) - and indicated where these are significant. 
The GARCH model has changed the estimates of the mean equation (5) in two ways. The run-up in returns prior to a stock dividend no longer appears significant. On the other hand, the fall in returns after a reduced dividend does now appear significant. The rise in returns after an improved cash dividend remains significant.

The estimated coefficients in the variance equation are also interesting. The model shows very strong GARCH effects, with highly significant coefficients $c_{1}$ and $c_{2}$. The value of 0.79 for $c_{2}$ implies a high degree of persistence, so that any shock to returns will raise variance for many days thereafter.

The coefficient $b_{12}$ is not significantly different from zero, so there is no event-related increase in the variance in the 10 days before a stock dividend. The presence of a stock dividend does not in itself shift the variance upwards before the event. However, there is a marked increase in variance on the day of the stock dividend distribution, as shown by the significance of coefficient $b_{13}$. Stock dividend distributions therefore typically cause a large unexpected jump up or down in price on the day of their payment. These jumps raise the variance of returns after the event day through the GARCH effect. However, the coefficient $b_{14}$ is significantly negative, meaning that the event-related conditional variance actually falls immediately after a pure stock dividend.

In this case and others, the net effects implied for pre- and post-dividend event variances are hard to judge from the model coefficients alone. We have already seen in Figure 4 the implications of the model for the variance of returns on shares paying increased cash dividends. On Figure 5 we simulate the behavior of the conditional variance for all types of event. In all cases, there is some increase in postevent variance. The large event day price movement associated with the pure stock dividend leads to a particularly large increase in variance on the dividend day. However, the post-dividend fall in the eventrelated conditional variance causes the overall conditional variance to fall very rapidly thereafter, and the Figure shows that the variance returns to its long run level within the next 10 days.

This contrasts the case of a pure cash dividend increase examined earlier. Because in Table 6 the coefficients $b_{22}$ and $b_{24}$ are significantly positive, the event-related conditional variance of returns increases in advance of the improved dividend payment, and stays high after the dividend date. When combined with the GARCH persistence effect, the result is a steady rise and a very gradual fall in volatility, with the variance still higher than its long run level 30 days after the dividend date. 
When the stock dividend is paid alongside a cash dividend, there are also some weak interaction effects. A stock dividend combined with an increased or decreased cash dividend results in the same kind of event-day jump in variance as the pure stock dividend, but of a smaller magnitude. However, the variance remains higher for longer after the dividend date, due to the rise in event-related variance associated with an improved cash dividend, and the roughly constant event-related conditional variance following a reduced cash dividend.

\section{CONCLUDING COMMENTS}

This paper set out to establish whether there were systematic patterns in returns associated with the many stock dividend payments made by companies listed on the ISE, and whether these resembled the patterns observed around stock splits and dividends in the US market.

Stock dividend payments on the ISE are not motivated by the same factors - such as past or prospective outperformance - which trigger stock splits in more developed markets. They are largely driven by accounting and regulatory considerations. However, the presence of stock dividend payments on the ISE do appear to lead investors to behave irrationally, to treat the stock dividends as substitutes for cash dividends and as an effective discount on the price of rights issues. We find that shares on the ISE which offer a stock dividend alongside a reduced cash dividend do not suffer the same adverse reaction as shares which simply cut their cash dividend.

Although there appears to be an anticipatory rise in the price of shares paying stock dividends similar to that observed in the US, this effect becomes statistically insignificant once proper account is taken of the way the return variance changes before and after the dividend is paid. This is consistent with the findings of Aydogan and Muradoglu (1998), who from a conventional event study methodology find no systematic price reactions around the announcement and payment of a number of stock dividends and rights issues on the ISE in the period 1988-93.

In contrast, cash dividend payments do have a significant impact on excess returns. There is no systematic movement in price in the weeks before the dividend payment date. But after the dividend date, the price of shares which pay an improved dividend rise, and the prices of shares which pay a lower dividend fall. This suggests that the ISE is informationally inefficient, in that news about cash 
dividends - which are announced from one to three months earlier - is absorbed only partially in advance of their actual payment.

The main technical innovation in the paper is the use of a GARCH model with event-dependent intercept terms to track changes in variances around event dates. The model reveals that share prices are exceptionally volatile on the day of a stock dividend payment. Prices are also volatile after the stock dividend payment, but this reflects a market reaction to the volatility around the dividend date - that is, conditional heteroscedasticity - rather than a post-event upward shift in the level of the returns variance. We conjecture that this reflects some confusion about whether the stock dividend will have a real effect on relative share prices, a confusion which is resolved in the two weeks following the dividend distribution.

This contrasts with the case of an increased cash dividend, where the level of the variance does rise temporarily before and after the dividend payment, a phenomenon which may reflect an increased trading in these shares, and which deserves further investigation in a model with volume-dependent volatility.

An increase in variance after stock splits has also been observed in the US stock market, but no good rationale has been provided. The GARCH effect identified here offers a possible explanation for this effect, and suggests that it may be productive to apply our methodology to other markets and other types of events where variance anomalies have appeared. This does of course beg the much larger question of why GARCH-type effects are so omnipresent in financial markets.

\section{REFERENCES}

Akgiray, V., "Conditional heteroscedasticity in time series of stock returns", Journal of Business, 62, (1989), 55-80.

Angel, J. J., “Tick size, share prices and stock splits”, Working Paper FINC 1377-11-694, Georgetown University School of Business,(1996).

Aydogan, K., and G. Muradoglu, 1998, "Do markets learn from experience? Price reactions to stock dividends in the Turkish market", Applied Financial Economics, 8, 41-49. 
Baker, H. and P Gallagher, "Management's view of stock splits", Financial Management, 9, (1980), 73-77.

Berndt, E. K., B. H. Hall, R. E. Hall and J. A. Hausman, "Estimation and inference in nonlinear structural models", Annals of Economic and Social Measurement, 4, (1974), 653-665.

Boehmer, E., Musumeci, J. and A. Poulsen, "Event-study methodology under conditions of eventinduced variance", Journal of Financial Economics, 30, (1991), 253-272.

Bollerslev, T., "Generalized autoregressive conditional heteroscedasticity", Journal of Econometrics, 31, (1986), 307-328.

Brown, S. and J. Warner, "Using daily stock returns: the case of event studies", Journal of Financial Economics, 14, (1985), 3-31.

Fama, E. F., L. Fisher, M. C. Jensen, and R. Roll, "The adjustment of stock prices to new information", International Economic Review, 10, (1969), 1-21.

French, D. W. and D. A. Dubovsky, "Stock splits and implied stock price volatility", Journal of Portfolio Management, 12, (1986), 55-59.

Grinblatt, M., R. Masulis and S. Titman, "The valuation of stock splits and stock dividends", Journal of Financial Economics, 13, (1984), 461-90.

Guldimann, T. M., RiskMetrics - Technical Document, J. P. Morgan: NewYork, (1995).

Harris, L., "Minimum price variations, discrete bid-ask spreads and quotation sizes", Review of Financial Studies, 7, (1994), 149-78.

Lakonishok, J. and B. Lev, Stock dividends: Why, who and when”, Journal of Finance, 42, (1987), 913-932.

Ohlson, J. and S. Penman, "Volatility increases subsequent to stock splits; an empirical aberration", Journal of Financial Economics, 14, (1985), 251-66.

de Santis, G. and S. Imrohoroglu, "Stock returns and volatility on emerging financial markets", Journal of International Money and Finance, 16, (1997), 561-97.

Sheikh, A. M., "Stock splits, volatility increases, and implied volatilities", Journal of Finance, 44, (1989), 1361-1372. 
Table 1. Characteristics of Leading ISE shares

\begin{tabular}{|c|c|c|c|c|c|c|}
\hline \multirow[t]{2}{*}{ Company } & \multirow{2}{*}{$\begin{array}{c}\text { Market Value } \\
\text { end-94, TL million }\end{array}$} & \multirow{2}{*}{$\begin{array}{l}\text { Daily Returns } \\
\text { Mean/ SD }\end{array}$} & \multicolumn{2}{|c|}{ Market Model: } & \multirow[b]{2}{*}{$\gamma$} & \multirow[b]{2}{*}{$\mathrm{R}^{2} / \mathrm{SE}$} \\
\hline & & & $\alpha$ & $\beta$ & & \\
\hline Arcelik & 25000 & $\begin{array}{l}0.2692 \\
(4.32)\end{array}$ & $\begin{array}{l}.7217 \\
(.39)\end{array}$ & $\begin{array}{l}1.0118 \\
(0.02)\end{array}$ & $\begin{array}{c}-2.9253 \\
(1.75)\end{array}$ & $\begin{array}{c}0.49 \\
(3.10)\end{array}$ \\
\hline Bagfas & 1620 & $\begin{array}{l}0.1955 \\
(4.66)\end{array}$ & $\begin{array}{c}-0.3270 \\
(0.42)\end{array}$ & $\begin{array}{l}1.0942 \\
(0.02)\end{array}$ & $\begin{array}{l}1.3534 \\
(1.88)\end{array}$ & $\begin{array}{c}0.49 \\
(3.33)\end{array}$ \\
\hline Celik Halat & 1032 & $\begin{array}{l}0.2090 \\
(4.94)\end{array}$ & $\begin{array}{c}0.2394 \\
(0.50)\end{array}$ & $\begin{array}{l}1.0055 \\
(0.03)\end{array}$ & $\begin{array}{c}-1.0571 \\
(2.22)\end{array}$ & $\begin{array}{c}0.37 \\
(3.93)\end{array}$ \\
\hline Cimsa & 5560 & $\begin{array}{c}0.2332 \\
(4.44)\end{array}$ & $\begin{array}{l}0.3187 \\
(0.44)\end{array}$ & $\begin{array}{l}0.9222 \\
(0.03)\end{array}$ & $\begin{array}{c}-1.2290 \\
(1.97)\end{array}$ & $\begin{array}{c}0.38 \\
(3.49)\end{array}$ \\
\hline $\begin{array}{l}\text { Cukurova } \\
\text { Elektrik }\end{array}$ & 5000 & $\begin{array}{c}0.2479 \\
(4.69)\end{array}$ & $\begin{array}{c}0.5409 \\
(0.45)\end{array}$ & $\begin{array}{l}1.0073 \\
(0.03)\end{array}$ & $\begin{array}{c}-2.2426 \\
(1.04)\end{array}$ & $\begin{array}{c}0.41 \\
(3.60)\end{array}$ \\
\hline Doktas & 1800 & $\begin{array}{l}0.1903 \\
(4.57)\end{array}$ & $\begin{array}{l}0.5186 \\
(0.45)\end{array}$ & $\begin{array}{c}0.9714 \\
(0.03)\end{array}$ & $\begin{array}{c}-2.3687 \\
(1.99)\end{array}$ & $\begin{array}{c}0.40 \\
(3.53)\end{array}$ \\
\hline $\begin{array}{l}\text { Eczacibasi } \\
\text { Yatirim }\end{array}$ & 1064 & $\begin{array}{l}0.3186 \\
(4.86)\end{array}$ & $\begin{array}{c}0.4554 \\
(0.48)\end{array}$ & $\begin{array}{l}1.0271 \\
(0.03)\end{array}$ & $\begin{array}{c}-1.5564 \\
(2.13)\end{array}$ & $\begin{array}{c}0.40 \\
(3.77)\end{array}$ \\
\hline Ege Biracilik & 16793 & $\begin{array}{c}0.4118 \\
(4.16)\end{array}$ & $\begin{array}{l}0.5297 \\
(0.41)\end{array}$ & $\begin{array}{l}0.8845 \\
(0.02)\end{array}$ & $\begin{array}{c}-1.3410 \\
(1.81)\end{array}$ & $\begin{array}{c}0.40 \\
(3.21)\end{array}$ \\
\hline $\begin{array}{l}\text { Eregli Demir } \\
\text { Celik }\end{array}$ & 22176 & $\begin{array}{c}0.2600 \\
(4.47)\end{array}$ & $\begin{array}{c}-0.2930 \\
(.38)\end{array}$ & $\begin{array}{l}1.0976 \\
(0.02)\end{array}$ & $\begin{array}{l}1.4867 \\
(0.86)\end{array}$ & $\begin{array}{c}0.54 \\
(3.04)\end{array}$ \\
\hline Good-year & 4332 & $\begin{array}{l}0.1998 \\
(4.42)\end{array}$ & $\begin{array}{c}0.0309 \\
(0.46)\end{array}$ & $\begin{array}{c}0.8682 \\
(0.03)\end{array}$ & $\begin{array}{c}-0.0329 \\
(2.02)\end{array}$ & $\begin{array}{c}0.34 \\
(3.58)\end{array}$ \\
\hline Guney Biracilik & 3289 & $\begin{array}{l}0.3176 \\
(4.46)\end{array}$ & $\begin{array}{l}0.1360 \\
(0.43)\end{array}$ & $\begin{array}{l}0.9667 \\
(0.03)\end{array}$ & $\begin{array}{c}-0.0654 \\
(1.93)\end{array}$ & $\begin{array}{c}0.42 \\
(3.41)\end{array}$ \\
\hline Kartonsan & 4995 & $\begin{array}{c}0.2583 \\
(4.11)\end{array}$ & $\begin{array}{c}-0.0640 \\
(0.40)\end{array}$ & $\begin{array}{c}0.8911 \\
(0.02)\end{array}$ & $\begin{array}{c}0.6390 \\
(1.77)\end{array}$ & $\begin{array}{c}0.42 \\
(3.13)\end{array}$ \\
\hline Koc Holdings & 57000 & $\begin{array}{c}0.2754 \\
(4.22)\end{array}$ & $\begin{array}{l}0.5215 \\
(0.37)\end{array}$ & $\begin{array}{l}1.0113 \\
(0.02)\end{array}$ & $\begin{array}{c}-2.0349 \\
(1.66)\end{array}$ & $\begin{array}{c}0.51 \\
(2.94)\end{array}$ \\
\hline Koc Yatirim & 5400 & $\begin{array}{c}0.2636 \\
(4.21)\end{array}$ & $\begin{array}{c}0.6259 \\
(0.39)\end{array}$ & $\begin{array}{c}0.9783 \\
(0.02)\end{array}$ & $\begin{array}{c}-2.5289 \\
(1.71)\end{array}$ & $\begin{array}{c}0.48 \\
(3.03)\end{array}$ \\
\hline Otosan & 8448 & $\begin{array}{l}0.2617 \\
(4.58)\end{array}$ & $\begin{array}{c}0.7546 \\
(0.44)\end{array}$ & $\begin{array}{l}1.0028 \\
(0.02)\end{array}$ & $\begin{array}{c}-3.1397 \\
(1.96)\end{array}$ & $\begin{array}{c}0.43 \\
(3.47)\end{array}$ \\
\hline Sarkuysan & 4253 & $\begin{array}{c}0.2760 \\
(3.99)\end{array}$ & $\begin{array}{c}0.2946 \\
(0.35)\end{array}$ & $\begin{array}{l}0.9835 \\
(0.02)\end{array}$ & $\begin{array}{c}-0.9835 \\
(1.53)\end{array}$ & $\begin{array}{c}0.54 \\
(2.71)\end{array}$ \\
\hline T. Is Bankasi & 19587 & $\begin{array}{l}0.3317 \\
(5.03)\end{array}$ & $\begin{array}{c}-0.3980 \\
(0.53)\end{array}$ & $\begin{array}{c}0.9628 \\
(0.03)\end{array}$ & $\begin{array}{c}2.4102 \\
(2.33)\end{array}$ & $\begin{array}{c}0.33 \\
(4.13)\end{array}$ \\
\hline T. Siemens & 4536 & $\begin{array}{c}0.2118 \\
(4.63)\end{array}$ & $\begin{array}{c}-0.2370 \\
(0.44)\end{array}$ & $\begin{array}{l}1.0280 \\
(0.03)\end{array}$ & $\begin{array}{l}1.0809 \\
(1.96)\end{array}$ & $\begin{array}{c}0.44 \\
(3.47)\end{array}$ \\
\hline T. Demir Dokum & 5000 & $\begin{array}{c}0.1930 \\
(4.40)\end{array}$ & $\begin{array}{c}0.4524 \\
(0.42)\end{array}$ & $\begin{array}{c}0.9751 \\
(0.02)\end{array}$ & $\begin{array}{c}-2.0617 \\
(1.86)\end{array}$ & $\begin{array}{c}0.44 \\
(3.30)\end{array}$ \\
\hline Yasas & 1154 & $\begin{array}{c}0.2684 \\
(4.70)\end{array}$ & $\begin{array}{c}0.0648 \\
(0.47)\end{array}$ & $\begin{array}{c}0.9564 \\
(0.03)\end{array}$ & $\begin{array}{c}0.0430 \\
(2.10)\end{array}$ & $\begin{array}{c}0.37 \\
(3.73)\end{array}$ \\
\hline ISE Market & 891064 & $\begin{array}{c}0.2029 \\
(2.98)\end{array}$ & & & & \\
\hline
\end{tabular}

Note: Figures in parentheses under estimated coefficients are standard errors. SD is the standard deviation of daily percentage log-returns, and SE is the standard error of the regression residuals. 
Table 2. Dividend Events by Company

\begin{tabular}{|c|c|c|c|c|c|c|c|}
\hline Company & $\begin{array}{c}\text { Total } \\
\text { Dividend } \\
\text { Events }\end{array}$ & $\begin{array}{c}\text { Stock } \\
\text { Dividend } \\
\text { Only }\end{array}$ & $\begin{array}{c}\text { Cash } \\
\text { Dividend } \\
\text { Up }\end{array}$ & $\begin{array}{c}\text { Cash } \\
\text { Dividend } \\
\text { Down }\end{array}$ & $\begin{array}{c}\text { Stock } \\
\text { Dividend + } \\
\text { Cash Up }\end{array}$ & $\begin{array}{c}\text { Stock } \\
\text { Dividend + } \\
\text { Cash Down }\end{array}$ & $\begin{array}{l}\text { With } \\
\text { Rights } \\
\text { Issue }\end{array}$ \\
\hline Arcelik & 6 & 1 & 0 & 0 & 3 & 2 & 5 \\
\hline Bagfas & 5 & 0 & 3 & 1 & 1 & 0 & 1 \\
\hline Celik Halat & 6 & 1 & 1 & 2 & 0 & 2 & 3 \\
\hline Cimsa & 5 & 0 & 3 & 1 & 0 & 1 & 1 \\
\hline Cukurova Elektrik & 5 & 0 & 3 & 2 & 0 & 0 & 4 \\
\hline Doktas & 5 & 0 & 0 & 0 & 3 & 2 & 4 \\
\hline Eczacibasi Yatirim & 5 & 0 & 0 & 1 & 3 & 1 & 4 \\
\hline Ege Biracilik & 5 & 0 & 1 & 1 & 2 & 1 & 1 \\
\hline Eregli Demir Celik & 5 & 0 & 1 & 1 & 1 & 2 & 3 \\
\hline Good-year & 5 & 0 & 0 & 0 & 3 & 2 & 2 \\
\hline Guney Biracilik & 5 & 0 & 1 & 1 & 2 & 1 & 1 \\
\hline Kartonsan & 6 & 1 & 1 & 1 & 3 & 0 & 3 \\
\hline Koc Holdings & 6 & 1 & 1 & 0 & 2 & 2 & 5 \\
\hline Koc Yatirim & 5 & 0 & 0 & 0 & 5 & 0 & 3 \\
\hline Otosan & 5 & 0 & 0 & 2 & 3 & 0 & 3 \\
\hline Sarkuysan & 5 & 0 & 1 & 1 & 3 & 0 & 3 \\
\hline T. Is Bankasi & 5 & 0 & 3 & 2 & 0 & 0 & 1 \\
\hline T. Siemens & 9 & 4 & 3 & 2 & 0 & 0 & 1 \\
\hline T. Demir Dokum & 7 & 2 & 1 & 1 & 3 & 0 & 5 \\
\hline Yasas & 5 & 0 & 2 & 1 & 1 & 1 & 2 \\
\hline Total Sample & 110 & 10 & 25 & 20 & 38 & 17 & 54 \\
\hline
\end{tabular}

Table 3. Cash Dividends, Stock Dividends and Rights Issues

\begin{tabular}{|l|c|c|c|c|}
\hline \multicolumn{1}{|c|}{$\begin{array}{c}\text { Type of } \\
\text { Event }\end{array}$} & $\begin{array}{c}\text { Number } \\
\text { of } \\
\text { Events }\end{array}$ & $\begin{array}{c}\text { Average } \\
\text { Cash } \\
\text { Dividend } \\
(\%)\end{array}$ & $\begin{array}{c}\text { Average } \\
\text { Stock } \\
\text { Dividend } \\
(\%)\end{array}$ & $\begin{array}{c}\text { Number } \\
\text { with } \\
\text { Rights Issue }\end{array}$ \\
\hline Stock Dividend Only & 10 & - & 83 & 4 \\
Cash Dividend Up & 25 & 232 & - & 4 \\
Cash Dividend Down & 20 & 76 & - & 13 \\
$\begin{array}{l}\text { Stock Dividend + } \\
\text { Cash Dividend Up }\end{array}$ & 38 & 102 & 96 & 13 \\
$\begin{array}{l}\text { Stock Dividend + } \\
\text { Cash Dividend Down }\end{array}$ & 17 & 46 & 53 & \\
\hline
\end{tabular}


Table 4. Mean daily excess return (100 $\left.\mathrm{rit}_{\mathrm{it}}\right)$ and standard deviation of daily excess returns around event days

\begin{tabular}{|c|c|c|c|c|c|c|}
\hline Event & $\begin{array}{l}\text { No. of } \\
\text { Events }\end{array}$ & $\begin{array}{c}11-30 \text { days } \\
\text { before }\end{array}$ & $\begin{array}{c}1-10 \text { days } \\
\text { before }\end{array}$ & $\begin{array}{c}\text { Event } \\
\text { day }\end{array}$ & $\begin{array}{c}1-10 \text { days } \\
\text { after }\end{array}$ & $\begin{array}{c}\text { 11-30 days } \\
\text { after }\end{array}$ \\
\hline Stock Dividend Only & 10 & $\begin{array}{l}-0.0845 \\
(3.68)\end{array}$ & $\begin{array}{l}0.7827 \\
(3.72)\end{array}$ & $\begin{array}{l}-0.6461 \\
(7.20)\end{array}$ & $\begin{array}{l}-0.3704 \\
(4.14)\end{array}$ & $\begin{array}{l}-0.0929 \\
(3.48)\end{array}$ \\
\hline Cash Dividend Up & 25 & $\begin{array}{l}0.0204 \\
(3.53)\end{array}$ & $\begin{array}{l}0.1274 \\
(3.46)\end{array}$ & $\begin{array}{c}0.8051 \\
(3.61)\end{array}$ & $\begin{array}{l}0.7099 \\
(4.25)\end{array}$ & $\begin{array}{l}-0.1974 \\
(3.76)\end{array}$ \\
\hline Cash Dividend Down & 20 & $\begin{array}{l}0.0126 \\
(3.55)\end{array}$ & $\begin{array}{l}-0.0208 \\
(3.62)\end{array}$ & $\begin{array}{l}1.0405 \\
(3.91)\end{array}$ & $\begin{array}{c}-0.3962 \\
(4.27)\end{array}$ & $\begin{array}{c}0.0301 \\
(3.71)\end{array}$ \\
\hline $\begin{array}{l}\text { Stock Dividend }+ \\
\text { Cash Dividend Up }\end{array}$ & 38 & $\begin{array}{l}0.1331 \\
(3.61)\end{array}$ & $\begin{array}{c}0.2294 \\
(3.68)\end{array}$ & $\begin{array}{l}1.4059 \\
(4.30)\end{array}$ & $\begin{array}{l}-0.0702 \\
(3.79)\end{array}$ & $\begin{array}{c}-0.0209 \\
(3.50)\end{array}$ \\
\hline $\begin{array}{l}\text { Stock Dividend }+ \\
\text { Cash Dividend Down }\end{array}$ & 17 & $\begin{array}{l}0.2037 \\
(3.31)\end{array}$ & $\begin{array}{l}0.4227 \\
(3.25)\end{array}$ & $\begin{array}{c}2.4941 \\
(3.58)\end{array}$ & $\begin{array}{c}0.1789 \\
(3.86)\end{array}$ & $\begin{array}{l}-0.5100 \\
(3.21)\end{array}$ \\
\hline
\end{tabular}

Note: standard deviation of returns in parentheses

Table 5. OLS model for excess returns around event dates

\begin{tabular}{|c|c|c|c|c|}
\hline Variable & & $\begin{array}{c}\text { 1-10 days before } \\
\mathrm{j}=2\end{array}$ & $\begin{array}{l}\text { Event day } \\
\quad \mathrm{j}=3\end{array}$ & $\begin{array}{c}\text { 1-10 days after } \\
\mathrm{j}=4\end{array}$ \\
\hline $\begin{array}{l}\text { Constant } \\
\text { (11-30 days before/ after) }\end{array}$ & $\begin{array}{c}-0.0264 \\
(0.48)\end{array}$ & & & \\
\hline Stock Dividend & & $\begin{array}{c}0.8089 * \\
(2.21)\end{array}$ & $\begin{array}{l}-0.6185 \\
(0.54)\end{array}$ & $\begin{array}{c}-0.3444 \\
(0.94)\end{array}$ \\
\hline Cash Dividend Up & & $\begin{array}{l}0.1540 \\
(0.65)\end{array}$ & $\begin{array}{c}0.8312 \\
(1.14)\end{array}$ & $\begin{array}{c}0.7364 * \\
(3.12)\end{array}$ \\
\hline Cash Dividend Down & & $\begin{array}{l}0.0055 \\
(0.02)\end{array}$ & $\begin{array}{l}1.0674 \\
(1.31)\end{array}$ & $\begin{array}{l}-0.3700 \\
(1.41)\end{array}$ \\
\hline Stock Div + Cash Div Up & & $\begin{array}{l}-0.7071 \\
(1.50)\end{array}$ & $\begin{array}{l}1.2193 \\
(0.82)\end{array}$ & $\begin{array}{l}-0.4361 \\
(0.92)\end{array}$ \\
\hline Stock Div + Cash Div Down & & $\begin{array}{c}-0.3653 \\
(0.69)\end{array}$ & $\begin{array}{l}2.0705 \\
(1.25)\end{array}$ & $\begin{array}{c}0.9199 \\
(1.74)\end{array}$ \\
\hline
\end{tabular}

Notes: Regression Statistics: $\mathrm{R}^{2}=0.0035, \mathrm{SE}=3.6214$. Figures in parentheses under estimated coefficients are t-statistics. * indicates significance at the $5 \%$ level, ** at the $1 \%$ level. 
Table 6. EV-GARCH model of excess returns around event dates

\begin{tabular}{|c|c|c|c|c|}
\hline Variable & & $\begin{array}{c}\text { 1-10 days before } \\
\mathrm{j}=2\end{array}$ & $\begin{array}{c}\text { Event day } \\
\mathrm{j}=3\end{array}$ & $\begin{array}{c}1-10 \text { days after } \\
j=4\end{array}$ \\
\hline \multicolumn{5}{|l|}{ Equation for mean: } \\
\hline $\begin{array}{l}\text { Constant } \\
\text { (11-30 days before/ after) }\end{array}$ & $\begin{array}{l}-0.035 \\
(0.74)\end{array}$ & & & \\
\hline Stock Dividend & & $\begin{array}{l}0.2828 \\
(0.91)\end{array}$ & $\begin{array}{c}-0.8484 \\
(0.65)\end{array}$ & $\begin{array}{l}-0.1977 \\
(0.54)\end{array}$ \\
\hline Cash Dividend Up & & $\begin{array}{l}0.0357 \\
(0.16)\end{array}$ & $\begin{array}{c}0.7394 \\
(1.13)\end{array}$ & $\begin{array}{c}0.7304^{*} \\
(2.67)\end{array}$ \\
\hline Cash Dividend Down & & $\begin{array}{l}0.0429 \\
(0.21)\end{array}$ & $\begin{array}{l}1.0315 \\
(1.42)\end{array}$ & $\begin{array}{l}-0.5092 * \\
(2.39)\end{array}$ \\
\hline Stock Div + Cash Div Up & & $\begin{array}{l}-0.0919 \\
(0.22)\end{array}$ & $\begin{array}{l}1.1143 \\
(0.68)\end{array}$ & $\begin{array}{l}-0.6148 \\
(1.27)\end{array}$ \\
\hline Stock Div + Cash Div Down & & $\begin{array}{l}0.2368 \\
(0.51)\end{array}$ & $\begin{array}{l}1.7003 \\
(0.92)\end{array}$ & $\begin{array}{c}0.5793 \\
(1.14)\end{array}$ \\
\hline \multicolumn{5}{|l|}{ Equation for variance: } \\
\hline $\begin{array}{l}\text { Company-specific dummies: } \\
\text { (mean/ range) }\end{array}$ & $\begin{array}{c}0.8629 * \\
0.45 *-1.43 *\end{array}$ & & & \\
\hline Stock Dividend & & $\begin{array}{l}-0.0531 \\
(0.13)\end{array}$ & $\begin{array}{c}11.0113^{*} \\
(2.08)\end{array}$ & $\begin{array}{c}-0.6749 * \\
(2.48)\end{array}$ \\
\hline Cash Dividend Up & & $\begin{array}{l}0.6484 \\
(2.59)\end{array}$ & $\begin{array}{l}-1.0906 \\
(0.40)\end{array}$ & $\begin{array}{c}1.4096 * * \\
(4.65)\end{array}$ \\
\hline Cash Dividend Down & & $\begin{array}{l}-0.2196 \\
(0.86)\end{array}$ & $\begin{array}{l}5.1366 \\
(1.91)\end{array}$ & $\begin{array}{l}-0.3129 \\
(1.31)\end{array}$ \\
\hline Stock Div + Cash Div Up & & $\begin{array}{c}-0.5293 \\
(1.03)\end{array}$ & $\begin{array}{c}-2.0353 \\
(0.32)\end{array}$ & $\begin{array}{c}-1.0263^{*} \\
(2.36)\end{array}$ \\
\hline Stock Div + Cash Div Down & & $\begin{array}{c}0.7306 \\
(1.30)\end{array}$ & $\begin{array}{c}-15.0675^{*} \\
(2.22)\end{array}$ & $\begin{array}{c}1.1261 * \\
(2.53)\end{array}$ \\
\hline$v_{i t-1}{ }^{2}$ & $\begin{array}{c}0.1321 * * \\
(14.23)\end{array}$ & & & \\
\hline$h_{\text {it-1 }}$ & $\begin{array}{c}0.7950 * * \\
(60.80)\end{array}$ & & & \\
\hline
\end{tabular}

Notes: see Table 5. 

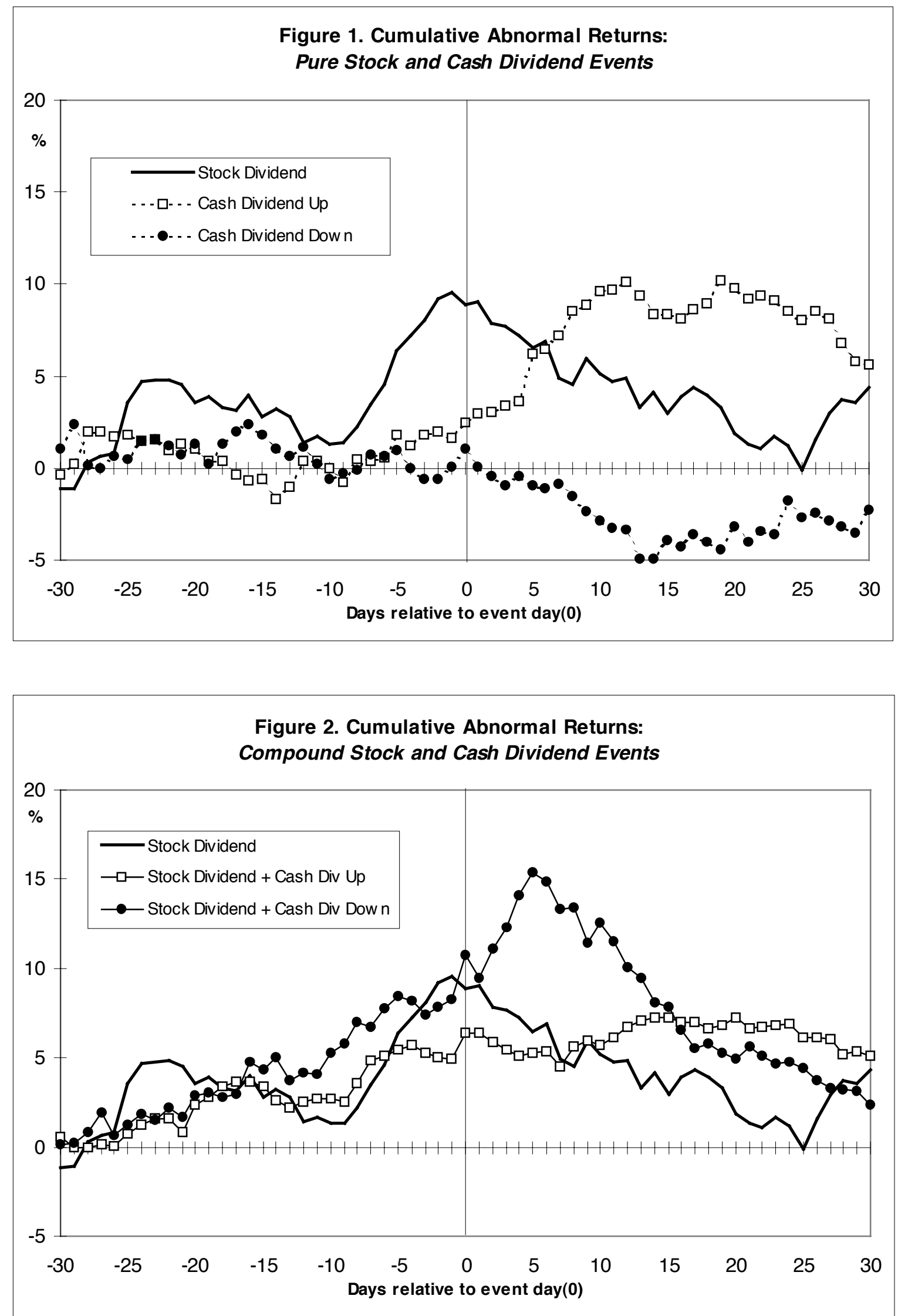


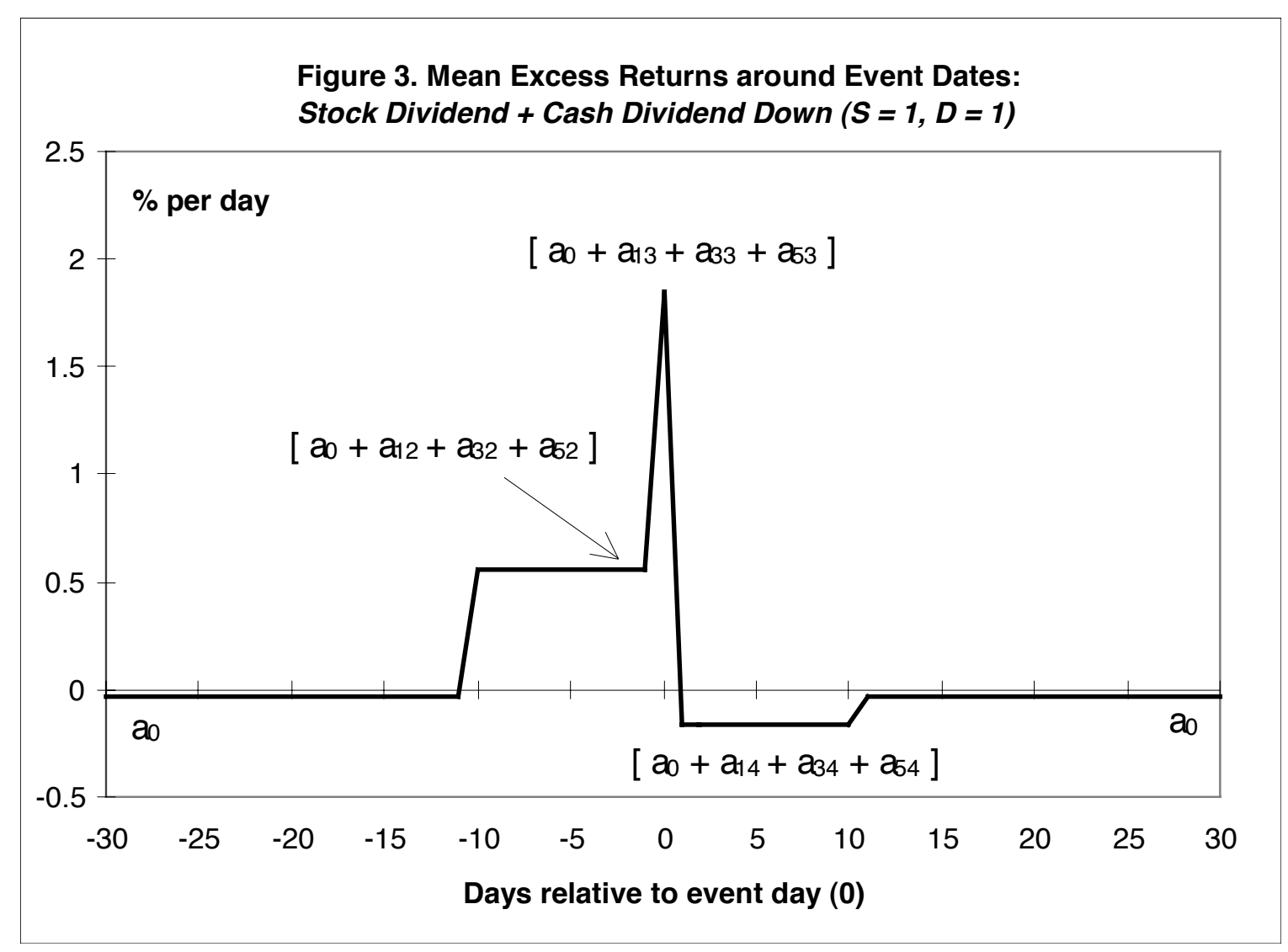

Figure 4. Variance of Excess Returns around Event Dates: Cash Dividend Up $(U=1)$

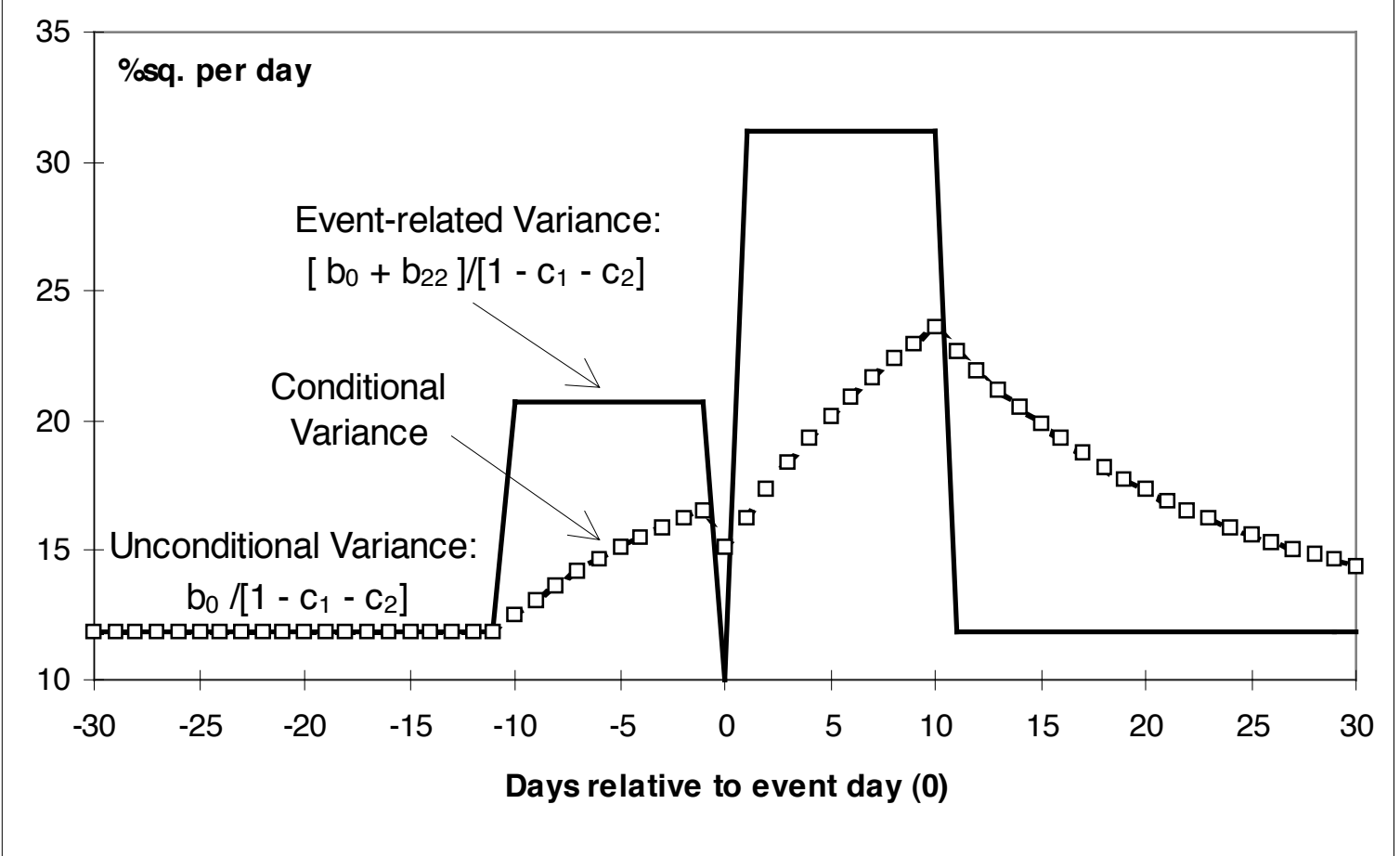


Figure 5. Simulated Volatility of Abnormal Returns around Event Dates

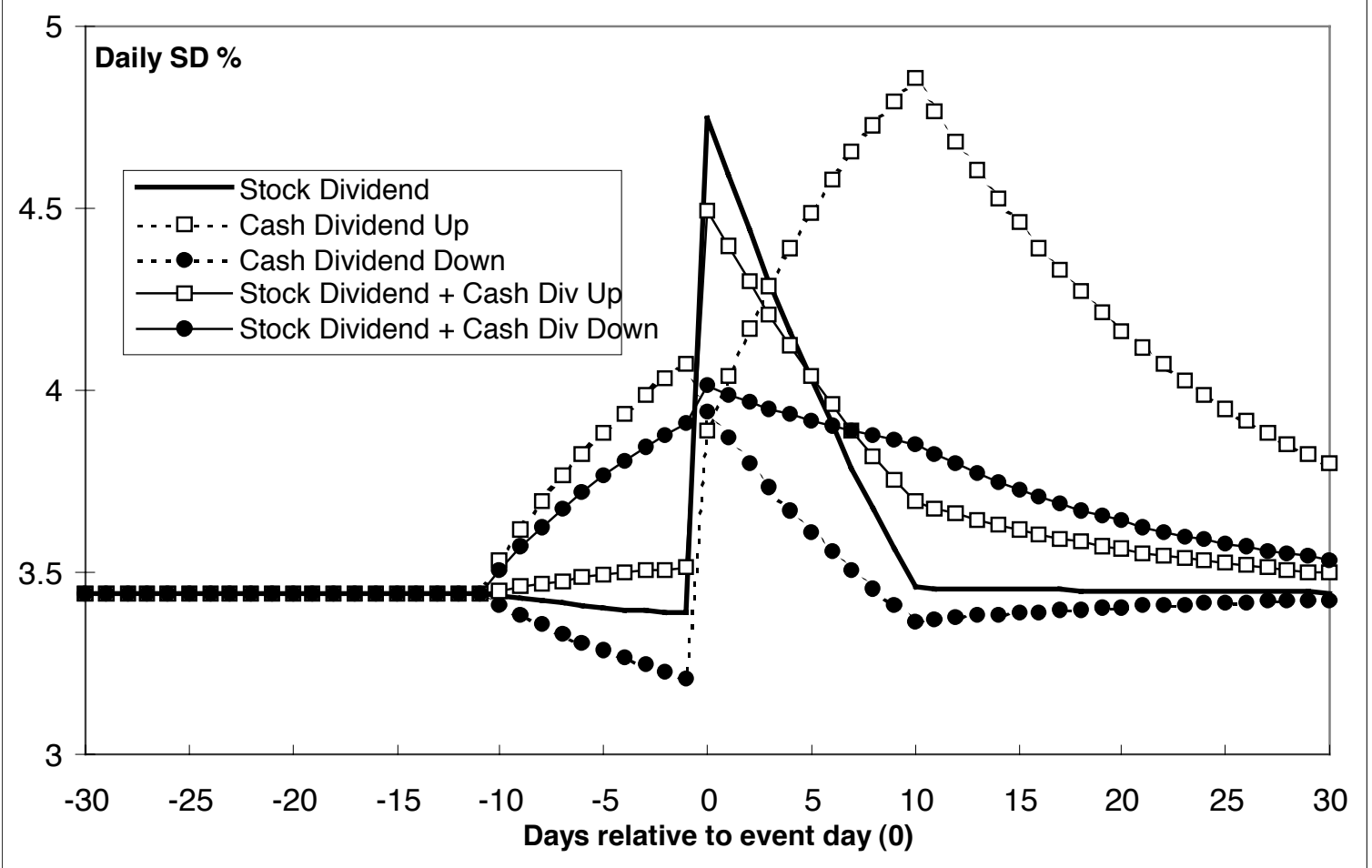




\section{List of other working papers:}

\section{2}

1. Paolo Zaffaroni, Gaussian inference on Certain Long-Range Dependent Volatility Models, WP02-12

2. Paolo Zaffaroni, Aggregation and Memory of Models of Changing Volatility, WP02-11

3. Jerry Coakley, Ana-Maria Fuertes and Andrew Wood, Reinterpreting the Real Exchange Rate - Yield Diffential Nexus, WP02-10

4. Gordon Gemmill and Dylan Thomas, Noise Training, Costly Arbitrage and Asset Prices: evidence from closed-end funds, WP02-09

5. Gordon Gemmill, Testing Merton's Model for Credit Spreads on Zero-Coupon Bonds, WP0208

6. George Christodoulakis and Steve Satchell, On th Evolution of Global Style Factors in the MSCI Universe of Assets, WP02-07

7. George Christodoulakis, Sharp Style Analysis in the MSCI Sector Portfolios: A Monte Caro Integration Approach, WP02-06

8. George Christodoulakis, Generating Composite Volatility Forecasts with Random Factor Betas, WP02-05

9. Claudia Riveiro and Nick Webber, Valuing Path Dependent Options in the Variance-Gamma Model by Monte Carlo with a Gamma Bridge, WP02-04

10. Christian Pedersen and Soosung Hwang, On Empirical Risk Measurement with Asymmetric Returns Data, WP02-03

11. Roy Batchelor and Ismail Orgakcioglu, Event-related GARCH: the impact of stock dividends in Turkey, WP02-02

12. George Albanis and Roy Batchelor, Combining Heterogeneous Classifiers for Stock Selection, WP02-01

\section{1}

1. Soosung Hwang and Steve Satchell, GARCH Model with Cross-sectional Volatility; GARCHX Models, WP01-16

2. Soosung Hwang and Steve Satchell, Tracking Error: Ex-Ante versus Ex-Post Measures, WP01-15

3. Soosung Hwang and Steve Satchell, The Asset Allocation Decision in a Loss Aversion World, WP01-14

4. Soosung Hwang and Mark Salmon, An Analysis of Performance Measures Using Copulae, WP01-13

5. Soosung Hwang and Mark Salmon, A New Measure of Herding and Empirical Evidence, WP01-12

6. Richard Lewin and Steve Satchell, The Derivation of New Model of Equity Duration, WP0111

7. Massimiliano Marcellino and Mark Salmon, Robust Decision Theory and the Lucas Critique, WP01-10

8. Jerry Coakley, Ana-Maria Fuertes and Maria-Teresa Perez, Numerical Issues in Threshold Autoregressive Modelling of Time Series, WP01-09

9. Jerry Coakley, Ana-Maria Fuertes and Ron Smith, Small Sample Properties of Panel Timeseries Estimators with I(1) Errors, WP01-08

10. Jerry Coakley and Ana-Maria Fuertes, The Felsdtein-Horioka Puzzle is Not as Bad as You Think, WP01-07

11. Jerry Coakley and Ana-Maria Fuertes, Rethinking the Forward Premium Puzzle in a Nonlinear Framework, WP01-06

12. George Christodoulakis, Co-Volatility and Correlation Clustering: A Multivariate Correlated ARCH Framework, WP01-05 
13. Frank Critchley, Paul Marriott and Mark Salmon, On Preferred Point Geometry in Statistics, WP01-04

14. Eric Bouyé and Nicolas Gaussel and Mark Salmon, Investigating Dynamic Dependence Using Copulae, WP01-03

15. Eric Bouyé, Multivariate Extremes at Work for Portfolio Risk Measurement, WP01-02

16. Erick Bouyé, Vado Durrleman, Ashkan Nikeghbali, Gael Riboulet and Thierry Roncalli, Copulas: an Open Field for Risk Management, WP01-01

\section{0}

1. Soosung Hwang and Steve Satchell, Valuing Information Using Utility Functions, WP00-06

2. Soosung Hwang, Properties of Cross-sectional Volatility, WP00-05

3. Soosung Hwang and Steve Satchell, Calculating the Miss-specification in Beta from Using a Proxy for the Market Portfolio, WP00-04

4. Laun Middleton and Stephen Satchell, Deriving the APT when the Number of Factors is Unknown, WP00-03

5. George A. Christodoulakis and Steve Satchell, Evolving Systems of Financial Returns: AutoRegressive Conditional Beta, WP00-02

6. Christian S. Pedersen and Stephen Satchell, Evaluating the Performance of Nearest Neighbour Algorithms when Forecasting US Industry Returns, WP00-01

\section{9}

1. Yin-Wong Cheung, Menzie Chinn and Ian Marsh, How do UK-Based Foreign Exchange Dealers Think Their Market Operates?, WP99-21

2. Soosung Hwang, John Knight and Stephen Satchell, Forecasting Volatility using LINEX Loss Functions, WP99-20

3. Soosung Hwang and Steve Satchell, Improved Testing for the Efficiency of Asset Pricing Theories in Linear Factor Models, WP99-19

4. Soosung Hwang and Stephen Satchell, The Disappearance of Style in the US Equity Market, WP99-18

5. Soosung Hwang and Stephen Satchell, Modelling Emerging Market Risk Premia Using Higher Moments, WP99-17

6. Soosung Hwang and Stephen Satchell, Market Risk and the Concept of Fundamental Volatility: Measuring Volatility Across Asset and Derivative Markets and Testing for the Impact of Derivatives Markets on Financial Markets, WP99-16

7. Soosung Hwang, The Effects of Systematic Sampling and Temporal Aggregation on Discrete Time Long Memory Processes and their Finite Sample Properties, WP99-15

8. Ronald MacDonald and Ian Marsh, Currency Spillovers and Tri-Polarity: a Simultaneous Model of the US Dollar, German Mark and Japanese Yen, WP99-14

9. Robert Hillman, Forecasting Inflation with a Non-linear Output Gap Model, WP99-13

10. Robert Hillman and Mark Salmon, From Market Micro-structure to Macro Fundamentals: is there Predictability in the Dollar-Deutsche Mark Exchange Rate?, WP99-12

11. Renzo Avesani, Giampiero Gallo and Mark Salmon, On the Evolution of Credibility and Flexible Exchange Rate Target Zones, WP99-11

12. Paul Marriott and Mark Salmon, An Introduction to Differential Geometry in Econometrics, WP99-10

13. Mark Dixon, Anthony Ledford and Paul Marriott, Finite Sample Inference for Extreme Value Distributions, WP99-09

14. Ian Marsh and David Power, A Panel-Based Investigation into the Relationship Between Stock Prices and Dividends, WP99-08

15. Ian Marsh, An Analysis of the Performance of European Foreign Exchange Forecasters, WP99-07

16. Frank Critchley, Paul Marriott and Mark Salmon, An Elementary Account of Amari's Expected Geometry, WP99-06

17. Demos Tambakis and Anne-Sophie Van Royen, Bootstrap Predictability of Daily Exchange Rates in ARMA Models, WP99-05

18. Christopher Neely and Paul Weller, Technical Analysis and Central Bank Intervention, WP9904

19. Christopher Neely and Paul Weller, Predictability in International Asset Returns: A Reexamination, WP99-03 
20. Christopher Neely and Paul Weller, Intraday Technical Trading in the Foreign Exchange Market, WP99-02

21. Anthony Hall, Soosung Hwang and Stephen Satchell, Using Bayesian Variable Selection Methods to Choose Style Factors in Global Stock Return Models, WP99-01

\section{8}

1. Soosung Hwang and Stephen Satchell, Implied Volatility Forecasting: A Compaison of Different Procedures Including Fractionally Integrated Models with Applications to UK Equity Options, WP98-05

2. Roy Batchelor and David Peel, Rationality Testing under Asymmetric Loss, WP98-04

3. Roy Batchelor, Forecasting T-Bill Yields: Accuracy versus Profitability, WP98-03

4. Adam Kurpiel and Thierry Roncalli, Option Hedging with Stochastic Volatility, WP98-02

5. Adam Kurpiel and Thierry Roncalli, Hopscotch Methods for Two State Financial Models, WP98-01 